complexes and low C3 concentrations have been shown in the past, ${ }^{3}$ but only one other patient has been treated by plasma exchange. This patient also responded. ${ }^{4}$ These reports suggest that in some patients with autoerythrocyte sensitisation there may be a specific immunological abnormality, but its exact nature and that of the myriad of psychological symptoms remain unexplained.

${ }^{1}$ Gardner FH, Diamond LK. Autoerythrocyte sensitisation. A form of purpura producing painful bruises following autosensitisation to red blood cells in certain women. Blood $1955 ; 10: 675-90$

2 Ratnoff OD. The psychogenic purpuras. Semin Hematol 1980;17:192-213.

${ }^{3}$ Krain LS, Levin JM, Schultz B. Decreased serum complement in Diamond Gardner syndrome. Immunofluorescent findings and association with angioimmunoblastic lymphadenopathy. Cutis 1978;21:80-4.

${ }^{4}$ Lockwood CM, Pearson T. Use of plasma exchange in the treatment of allergic disease. In: Proceedings of advanced component therapy seminar. Vol 3. Wayland, Mass: Haemonetics Research Institute, 1977.

(Accepted 25 August 1981)

Department of Haematology, Royal Victoria Hospital, Bournemouth BH1 4JG

T J HAMBLIN, MB, MRCPATH, consultant haematologist

$S$ HART, MB, BS, senior house officer

G J MUFTI, MB, BS, senior registrar

\section{Tuning-fork tests in diagnosis of serous otitis media}

Serous otitis media is the most common cause of hearing loss in childhood and its detection has required a considerable audiometric effort by community health services. The insidious nature of the condition causes great difficulties in diagnosis by general practitioners. The average hearing loss in serous otitis media was found by Brookes ${ }^{1}$ to be $14.7 \mathrm{~dB}$, whereas a loss of $19 \mathrm{~dB}$ or more was found by Golabek and Stephens ${ }^{2}$ to be necessary to produce a negative Rinne test. Our findings suggest that one or both of these figures may be wrong, and in our experience the average hearing loss is greater than $14 \cdot 7 \mathrm{~dB}$.

\section{Patients, methods, and results}

One hundred children aged 2-12 years and admitted for myringotomy were investigated by tuning-fork tests and pure-tone audiometry. The initial diagnosis was made clinically and by tympanometry. A tuning fork of $512 \mathrm{~Hz}$ was used in the paediatric ward with an ambient noise level of around $50 \mathrm{~dB}$. The Rinne test was performed by both loudness comparison and threshold techniques.

Six children under 4 failed to respond to the tuning-fork tests and puretone audiometry. Of the six children in the unilateral effusion group in which vibration in the Weber test was not referred, four had negative middleear pressures of $200 \mathrm{~mm} \mathrm{H}_{2} \mathrm{O}$ or more in the other ear, and one had a "flat" curve in the other ear on tympanometry. Three children with bilateral negative Rinne tests in the unilateral group also had a midline result in the Weber test and a negative pressure of $200 \mathrm{~mm} \mathrm{H} \mathrm{H}_{2} \mathrm{O}$ or more in the ear without effusion. In the no-effusion group three children had abnormal Rinne tests, but where the Rinne test was negative the tympanogram was flat. The table summarises these results.

\section{Comment}

Tuning-fork tests are a reliable method of diagnosing serous otitis media in children over 4 and do not make great demands on equipment, environment, or skill but do require co-operation from the

Results of tuning-fork tests and pure-tone audiometry in 94 children who responded to tuning-fork tests

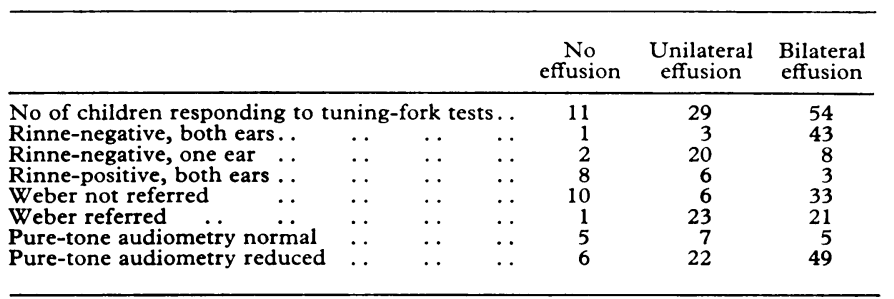

patients. Rinne tests were abnormal in 51 of the 54 children with bilateral effusion and 23 of the 29 with unilateral effusion. The abnormal tuning-fork test results in the no-effusion group correlated with hearing losses in pure-tone audiometry and flat tympanograms and were due to other causes of conductive deafness. Even under hospital conditions tuning-fork tests were more reliable than pure-tone audiometry when all three groups were considered together, and the results of pure-tone audiometry in the unilateral and no-effusion groups were no better than would be expected by chance $(p<0 \cdot 1)$

There are good grounds for tuning-fork tests being performed routinely by general practitioners on children over 4 suffering from earache or deafness, and possibly they would be a more effective test for serous otitis media in school screening tests than pure-tone audiometry. In an investigation comparing pure-tone audiometry with tympanometry as a screening test for hearing in 285 primaryschool children, pure-tone audiometry recognised only half the ears with serous otitis media, and about half the children failing pure-tone audiometry were subsequently found to have normal hearing. Similar results were reported by Harrison. ${ }^{3}$ Pure-tone audiometry in school screening tests where the ambient noise levels have peaks of $70 \mathrm{~dB}$ is therefore a very poor test and should be replaced either with impedence audiometry or possibly by tuning-fork tests combined with the presentation of one high-frequency tone at one intensity.

The diagnosis of serous otitis media in children below the age of 4 still rests mainly on the clinical appearance of the tympanic membrane combined with tympanometry. Tuning-fork tests are a cheap and effective way of diagnosing the conductive deafness of serous otitis media in children over 4 , and we have found that it is not difficult to obtain co-operation and accurate results.

${ }^{1}$ Brookes DN. La impedancimetria. Exploración y diagnostico. An Otor rinolaringol Ibero Am 1974;1:83-99.

${ }^{2}$ Golabek W, Stephens SDG. Some tuning fork tests revisited. Clin Otolaryngol $1979 ; 4: 421-30$.

${ }^{3}$ Harrison DR. An investigation into effects of ambient noise on puretone screening tests. Sound $1971 ; 5: 94-6$.

(Accepted 23 fune 1981)

Queen Elizabeth Hospital, King's Lynn, Norfolk PE30 4ET

$M$ W YUNG, MB, DLO, senior house officer

T M O MORRIS, FRCS, DLO, consultant ENT surgeon

\section{Lactic acidosis and Fanconi's syndrome due to degraded tetracycline}

The ingestion of degraded or outdated tetracycline is well known to result in the Fanconi syndrome, ${ }^{1}$ but, to our knowledge, lactic acidosis has not been reported in such circumstances. We describe a woman who after ingesting altered tetracycline developed simultaneously lactic acidosis and the Fanconi syndrome.

\section{Case report}

A 41-year-old woman took a self-prescribed dose of $4 \mathrm{~g}$ tetracycline over 48 hours because of toothache. The tablets had got wet accidentally over a year before, and she had dried them and kept them in a non-hermetic cardboard box. She denied fever, convulsions, alcohol, or ingestion of other drugs. She stopped taking the tetracycline because of vomiting, mild epigastric discomfort, and profound weakness, which lasted for three days, and was then admitted to hospital. On admission blood pressure was $120 / 80$ $\mathrm{mm} \mathrm{Hg}$, pulse rate $86 / \mathrm{min}$, and temperature $37.8^{\circ} \mathrm{C}$. Kussmaul breathing was noted. She was alert and well orientated and seemed moderately dehydrated. The rest of the physical examination was negative. Packed cell volume was $40 \%$ and white cell count $9 \cdot 3 \times 10^{9} / 1$ with normal differential. The table summarises the remaining laboratory findings. In addition, generalised hyperaminoaciduria was shown by ion-exchange chromatography. Hypo-osmolar urine unresponsive to exogenous vasopressin was also noted.

There was no clinical or laboratory evidence of hepatic disease.

Large amounts of sodium bicarbonate (1836 mmol ( $\mathrm{mEq}$ ) over three days) and potassium ( $520 \mathrm{mmol}(\mathrm{mEq})$ over three days) were required to correct the acidosis and maintain a normal serum potassium con entration. In addition, she was given phosphate supplements to treat hypophosphataemia. Four days after admission serum lactate concentration was still $5.35 \mathrm{mmol} / \mathrm{l}$ $(48 \mathrm{mg} / 100 \mathrm{ml})$. Throughout the treatment serum creatinine concentration was normal and serum uric acid values were below $149 \mu \mathrm{mol} / 1(2.5 \mathrm{mg} / 100$ 
$\mathrm{ml})$. Her condition improved slowly, and she was discharged after three weeks. Four months after the initial episode, taking no medication, she was considered to be cured; laboratory results are shown in the table.

Main laboratory data on admission and after full recovery

\begin{tabular}{|c|c|c|}
\hline & On admission & Four months later \\
\hline \multicolumn{3}{|l|}{ Serum } \\
\hline Glucose $(\mathrm{mmol} / \mathrm{l})$ & $4 \cdot 6$ & $5 \cdot 0$ \\
\hline Blood urea nitrogen ( $\mathrm{mmol} / \mathrm{l})$ & $5 \cdot 0$ & $5 \cdot 7$ \\
\hline Creatinine $(\mu \mathrm{mol} 1 \mathrm{l})$ & 88 & $71^{\circ}$ \\
\hline Uric acid $(\mu \mathrm{mol} / 1)$ & 125 & 262 \\
\hline Sodium $(\mathrm{mmol}(\mathrm{mEq}) \mathrm{l})$ & 141 & 143 \\
\hline Potassium (mmol(mEq) 1$)$ & $2 \cdot 9$ & 4 \\
\hline Chloride $(\mathrm{mmol}(\mathrm{mEq}) \mathrm{l})$ & 112 & 101 \\
\hline Bicarbonate $(\mathrm{mmol}(\mathrm{mEq}) \mathrm{l})$ & $3 \cdot 7$ & $21 \cdot 2$ \\
\hline Arterial pH & $7 \cdot 12$ & $7 \cdot 38$ \\
\hline Oxygen pressure $(\mathrm{mm} \mathrm{Hg})$ & 111 & 88 \\
\hline Carbon dioxide pressure $(\mathrm{mm} \mathrm{Hg})$ & $12 \cdot 4$ & $34 \cdot 4$ \\
\hline Calcium (mmol $/ 1)$ & 2.5 & $2 \cdot 4$ \\
\hline Phosphorus ( $\mathrm{mmol} / \mathrm{l})$ & $0 \cdot 39$ & $1 \cdot 2$ \\
\hline Magnesium $(\mu \mathrm{mol} / \mathrm{l})$ & 782 & ND \\
\hline Ketones & Negative & ND \\
\hline Lactate $(\mu \mathrm{mol} / 1)^{*}$ & 921 & ND \\
\hline Amylase (Somogyi units 1 ) & 900 & ND \\
\hline Anion gap (calculated mmol l) & $25 \cdot 3$ & $10 \cdot 8$ \\
\hline \multicolumn{3}{|l|}{ Urine } \\
\hline $\mathrm{pH}$ & 6 & $6 \cdot 8$ \\
\hline Proteinuria & $++t$ & Negative \\
\hline Glucosuria & $++t$ & Negative \\
\hline Sodium $(\mathrm{mmol}(\mathrm{mEq}) / 1)$ & 113 & ND \\
\hline Potassium $(\mathrm{mmol}(\mathrm{mEq}) / \mathrm{l})$ & 43 & $\mathrm{ND}$ \\
\hline Uric acid $(\mathrm{mmol} / 24 \mathrm{~h})$ & 200 & 132 \\
\hline Sediment & 10 white cells & Normal \\
\hline Phosphate clearance $(\mathrm{ml} / \mathrm{min})$ & pow & 15 \\
\hline
\end{tabular}

*Normal range $0.5-2 \mathrm{mmol} / 1$.

$\mathrm{ND}=$ Not done.

Conversion: SI to traditional units-Blood glucose: $1 \mathrm{mmol} / 1 \approx 18 \mathrm{mg} / 100 \mathrm{ml}$. Blood urea nitrogen: $1 \mathrm{mmol} 1 \approx 2 \cdot 8 \mathrm{mg} / 100 \mathrm{ml}$. Creatinine: $1 \mu \mathrm{mol} / 1 \approx 11.3 \mu \mathrm{m} / 100$ ml. Uric acid: $1 \mu \mathrm{mol} / \approx 16.8 \mu \mathrm{g} / 100 \mathrm{ml}$. Calcium: $1 \mathrm{mmol} / 1 \approx 4 \mathrm{mg} / 100 \mathrm{ml}$.
Phosphorus: $1 \mathrm{mmol} 1 \approx 3.1 \mathrm{mg} / 100 \mathrm{ml}$. Magnesium: $1 \mu \mathrm{mol} / 1 \approx 2.4 \mu \mathrm{g} / 100 \mathrm{ml}$. Phosphorus: $1 \mathrm{mmol} 1 \approx 3 \cdot 1 \mathrm{mg} / 100 \mathrm{ml}$. Magnesium: $1 \mu \mathrm{mol} / 1 \approx 2 \cdot 4 \mu \mathrm{g} / 100 \mathrm{ml}$. acid: $1 \mathrm{mmol} 24 \mathrm{~h} \approx 6 \mathrm{mg} / 24 \mathrm{~h}$.

Biochemical analysis of the remaining tablets kept in the original cardboard box detected the presence of 4-epianhydrotetracycline and anhydrotetracycline in a proportion of $60 \%$; the maximum tolerated content of these compounds is less than $3 \%$.

\section{Comment}

This patient showed all the main features of the Fanconi syndrome. The finding of degradation products in the tetracycline tablets provides strong evidence for their being the cause of this renal tubular dysfunction.

Severe metabolic acidosis was prominent. Renal tubular acidosis due to the Fanconi syndrome was undoubtedly partly responsible for this. The existence of hyperchloraemia and an inappropriately high urinary $\mathrm{pH}$ endorse this interpretation. An inappropriately high urinary $\mathrm{pH}$ implies a distal acidification defect, which is sometimes present in the Fanconi syndrome ${ }^{2}$ and adds to the generalised proximal tubular dysfunction. The increased anion gap, however, cannot be accounted for by renal tubular acidosis and was caused by the lactic acidosis, as shown by the raised serum lactate concentrations and the absence of other causes of high anion gap metabolic acidosis. ${ }^{3}$ Since lactic acidosis appeared simultaneously with the Fanconi syndrome and no other reason for it could be found ${ }^{4}$ it seems logical to assume that the degraded tetracycline tablets were also responsible for its development. The possibility of a coincidental spontaneous lactic acidosis is unlikely in this case.

We can find no report of an association between lactic acidosis and tetracycline intake in the absence of other drugs or diseases capable of inducing lactic acidosis by themselves. The mechanism by which degraded tetracycline may produce lactic acidosis remains unknown. The condition might result from a toxic effect of the drug at the cellular level, but direct evidence is lacking. Nevertheless, we believe that this observation should alert doctors to the possibility of intake of altered tetracycline in cases of lactic acidosis of obscure origin.

We thank Dr M Rodés, from the department of metabolopaties, Institut de Bioquimica Clinica "Flor de Maig," Fundació “Juan March" Cerdanyola (Barcelona), for measuring the urine amino-acids; Dr A Moreno and other staff from the medical department of the Compañia Española de Penicilina y Antibioticos SA (Madrid) for performing the biochemical analysis of the altered tablets; and Ms Isabel Roselló for secretarial help.

${ }^{1}$ Frimpter GW, Timpanelli AE, Eisenmenger WJ, Stein HS, Ehrlich LI. Reversible Fanconi syndrome caused by degraded tetracycline. $\mathcal{F} A M A$ 1963;184:111-3.
${ }^{2}$ Lee DBN, Drinkard JP, Rosen VJ, Gonick HC. The adult Fanconi syndrome. Medicine (Baltimore) 1972;51:107-38.

${ }^{3}$ Kaehny WD, Gabow PA. Pathogenesis and management of metabolic acidosis and alkalosis. In : Schrier RW, ed. Renal and electrolyte disorders. 2nd ed. Boston: Little Brown and Co, 1980:115-57.

${ }^{4}$ Kreisberg RA. Lactate homeostasis and lactic acidosis. Ann Intern Med $1980 ; 92: 227-37$.

(Accepted 12 August 1981)

Nephrology Service, Hospital Clínico y Provincial, University of Barcelona, Spain

JESÚS MONTOLIU, MD, attending physician

MONTSERRAT CARRERA, MD, resident physician

ALEJANDRO DARNELL, MD, section head

LUIS REVERT, MD, professor of medicine (nephrology)

\section{Severe peripheral neuropathy complicating legionnaires' disease}

Neurological disturbance, particularly mental confusion, is a common complication of legionnaires' disease. Case reports draw attention to evidence of central nervous system dysfunction, ${ }^{12}$ but we have found only a single example of clinically severe peripheral nerve disease. ${ }^{3}$ We report a case of legionnaires' disease complicated by a profound but reversible neuropathy.

\section{Case report}

A 43-year-old porter was found in a confused state at home after a week of flu-like symptoms. On admission to hospital he was feverish $\left(38.8^{\circ} \mathrm{C}\right)$ and dehydrated with clinical evidence of left lower-lobe pneumonia. He was disorientated but there were no focal neurological deficits. All the deep reflexes were difficult to obtain, and the plantar responses were extensor. The white cell count was normal $\left(8.2 \times 10^{9} / 1\left(8200 / \mathrm{mm}^{3}\right) ; 86 \%\right.$ neutrophils, $8 \%$ lymphocytes) but the plasma urea concentration was $11.7 \mathrm{mmol} / 1(70.5$ $\mathrm{mg} / 100 \mathrm{ml}$ ) and the serum aspartate aminotransferase activity $260 \mathrm{IU} / 1$. Chest radiography confirmed extensive consolidation in the left lung. Cerebrospinal fluid was normal (white cell count $2.0 \times 10^{6} / 1$, protein concentration $0.4 \mathrm{~g} / 1$, glucose concentration $4.0 \mathrm{mmol} / 1(72.1 \mathrm{mg} / 100 \mathrm{ml}))$. Subsequently Legionella pneumophila infection was diagnosed on the basis of a fourfold rise in fluorescent antibody titre.

Bulbar weakness with dysarthria, dysphagia, and nasal regurgitation of fluid became apparent on the fifth hospital day. Thereafter, as the confusion lessened increasingly severe limb weakness became apparent. The patient complained of distal numbness in arms and legs together with tingling and pronounced unsteadiness on attempting to walk. By his third week in hospital the bulbar palsy had disappeared. Examination then showed bilateral facial weakness but otherwise normal cranial nerves. Symmetrical wasting of the small hand muscles was evident together with noticeable distal weakness in arms and legs. The arms showed tremor on posturing and mild ataxia with use. There was moderate ataxia of the legs tested in the lying position and a more pronounced disturbance of gait and stance. The deep reflexes had disappeared but the plantar responses remained extensor. Subjective perversion of sensation to touch was present below the mid-calf on each side, and position sense was impaired at the fingers and toes. Vibration sense was lost below the iliac crests.

Nerve-conduction studies showed absent sensory action potentials in the arms and moderate slowing of motor conduction $(25 \mathrm{~m} / \mathrm{s}$ in the median nerve). A further specimen of cerebrospinal fluid four weeks after admission showed a protein concentration of $0.6 \mathrm{~g} / \mathrm{l}$.

During the next two months the patient's weakness and sensory signs gradually resolved, though the tendon reflexes remained absent and the plantar responses extensor.

\section{Comment}

Though there was evidence of disturbance of the central nervous system (mental disorientation and extensor plantar responses), the neurological signs that developed in this patient with legionnaires' disease indicated predominant peripheral nerve dysfunction. Cerebellar ataxia has been noted as a complication of legionnaires' disease, ${ }^{4}$ but our patient's weakness and sensory loss were the likely cause of his ataxia.

Acute polyneuropathy, commonly designated Guillain-Barré syndrome, is a well-recognised complication of many specific infective processes. A rising cerebrospinal fluid protein concentration reaching high values in four to six weeks is characteristic. Whether the 